\title{
REINFECTION WITH BORRELIA BURGDORFERI
}

SIR,-Lyme borreliosis, a tick-borne multisystem disorder caused by the spirochaete Borrelia burgdorferi, typically begins with erythema chronicum migrans and is sometimes followed by involvement of the heart, joints, and nervous system. ${ }^{1}$ Neurological manifestations include meningoradiculitis (Bannwarth's syndrome), meningitis, and encephalitis. ${ }^{24}$ The clinical diagnosis can be confirmed by finding antibodies to $B$ burgdorferi by indirect immunofluorescence or ELISA. ${ }^{5,6}$ We describe here a serologically and bacteriologically confirmed case of possible reinfection.

In September, 1983, 2 weeks after a tick bite on the right arm, a 59-year-old woman had erythema migrans around the bite site. She presented on Nov 15 with a painful meningoradiculitis and bilateral papilloedema. CSF analysis showed a lymphocytic pleocytosis (330 cells $/ \mu \mathrm{l})$ and an increase in total protein $(82 \mathrm{mg} / \mathrm{dl})$. Her serum IgG antibody titre against $B$ burgdorferi rose from less than 16 to 256 within 4 weeks (figure). $\mathrm{IgM}$ antibodies were not detected, and borreliae could not be isolated from the CSF. The patient was treated with intravenous penicillin ( 20 megaunits daily for 5 days, then 10 megaunits daily for 5 days) and oral methylprednisolone (70 mg daily over 2 weeks with decreasing dosage). On discharge (Dec 12) she was free of pain, with a slightly improved vision. Follow-up examinations showed residual bilateral papillatrophy. In October, 1984, the CSF was normal (1 cell $/ \mu \mathrm{l}$, total protein $37 \mathrm{mg} / \mathrm{dl})$.

On Oct 2,1985, the patient visited a forest. She did not recall any arthropod bites but on Oct 5 a painful redness developed on the right side of her chest. She presented on Oct 7 with an erythema chronicum migrans, about $20 \times 14 \mathrm{~cm}$. Spirochaetes were isolated at biopsy of the skin around the lesion after 4 weeks' incubation in modified Kelly's medium. Her serum IgG antibody titre against $B$ burgdorferi had been 16 on June 27,1985 but had risen to 64 on Oct 17 without a corresponding IgM increase. Treatment with minocycline $200 \mathrm{mg}$ daily by mouth for 14 days was successful.

In 1958 Hollström reported a case of recurrent erythema migrans 5 years after primary infection. ${ }^{7}$ Sköldenberg et al in 1983 described a patient with two episodes, 20 years apart, of erythema migrans and meningitis after a tick bite. ${ }^{8}$ Serological tests were not done on these patients. In Weber and colleagues' two patients with erythema migrans and reinfection after 5 and 7 years antibody titres against $B$ hurgdorferi did not increase"

In 1983 our patient had Lyme borreliosis with Bannwarth's syndrome. Her serum IgG titre against $B$ burgdorferi became negative within 10 months. Erythema chronicum migrans recurred 2 years later. The absence of $\mathrm{IgM}$ antibodies in acute manifestations of Lyme borreliosis has been described before. ${ }^{5,6}$ The 1985 episode presented after the patient had stayed for a long time in a forest in an area known to be endemic for $B$ burgdorferi infection. Despite the absence of a known tick bite we think that the second attack was a reinfection and not a recurrence. The skin sites involved were different in the two episodes.

Patients with Bannwarth's syndrome usually retain a significant IgG titre against $B$ burgdorferi for several years. ${ }^{5}$ Our patient's antibody titre was insignificant by 10 months. The antibiotic and/or corticosteroid treatment given for that first attack may explain the short-lived immunity, permitting reinfection after only 2 years.

$\begin{array}{ll}\begin{array}{l}\text { Departments of Neurology } \\ \text { and Dermatology, }\end{array} & \text { HANS-WALTER PFISTER } \\ \text { University of Munich, } & \text { UWE NEUBERT } \\ \text { Klinikum Grosshadern, } & \text { BETTINA WILSKE } \\ 8000 \text { Munich 70, West Germany; } & \text { VERA PREAC-MURSIC } \\ \text { and Max von Pettenkofer Institute } & \text { KARI. MAX EINHÄUPL } \\ \text { for Hygiene and Medical Mierobiology, } & \text { GIAN DOMENICO BORASI } \\ \text { University of Munich } & \end{array}$

University of Munich

GIAN DOMENICO BORASIO

1. Steere AC, Grodzicki RL, Kornblatt AN, et al. The spirochetal etiology of Lyme disease. $N$ Engl I Med 1983; 308: 733-42.

2 Pachner AR, Steere AC. The triad of neurologic manifestations of Lyme disease: Menungitus, cranial neuritis and radiculoneuritis. Nearology 1985; 35: 47-53.

3. Pfister H-W, Einhaupl KM, Preac-Mursic V, Wilske B, Schierz G. The spırochetal etiology of lymphocytic meningoradiculitis of Bannwarth (Bannwarth's syndrome), F Nerrol 1984; 231: 141-44.

4. Pfister H-W, Einhaupl KM, Preac-Mursic V, Wilske B. Similarity of neurological manufestations of Borreha burgdorfen infections in America and Europe. Neurology 1985; 35: 1393-94

5. Ackermann R, Kabatzki J, Boisten HP, et al. Spirochaten-Átiologie der Erythema chronicum migrans. Krankhet Dtsch Med W'schr 1984; 109: 92-97.

6. Wilske B, Schuerz G, Preac-Mursic V, Weber K, Pfister HW, Emhaupl KM Serological diagnosis of erythema migrans disease and related disorders. Infection 1984; 12: 331-37.

7. Hollstrom E. Penicillin treatment of erythema chronicum migrans Afzelius. Acto Derm-Vener 1958; 38: 285-89.

8. Sköldenberg B, Stiernstedt G, Garde A, Kolmodin G, Carlstrom A, Nord CE Chronic meningitis caused by a penicillin-sensitive microorganısm? Lancet 1983 ii: 75-78.

9. Weber K, Schierz G, Wilske B, et al. Reinfection in erythema mugrans disease. Infection 1986; 14: 32-35. 